\title{
Adaptive Comanagement: a Systematic Review and Analysis
}

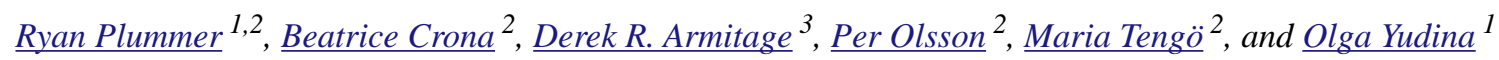

\begin{abstract}
This paper outlines the results of a systematic review of the literature on adaptive comanagement (ACM). Adaptive comanagement is an emergent governance approach for complex social-ecological systems that links the learning function of adaptive management (experimental and experiential) and the linking (vertically and horizontally) function of comanagement. Given the rapid growth of adaptive comanagement scholarship, there is value in a systematic analysis of how the concept is being conceptualized to elucidate agreement and discrepancies and to examine the challenges this presents for cross-case comparisons and the possibility of arriving at more generalizable insights. A synthesis-based methodology has been developed involving a comprehensive search and screening of academic databases and the internet. A detailed analysis of 108 documents was undertaken to characterize the state of the ACM literature, unpack the construct of ACM, and examine relationships among aspects of ACM based on accumulated experiences to date. The systematic review and analysis reveals imprecision, inconsistency, and confusion with the concept. Robust evidentiary insights into how the variables or components of ACM interrelate as well as relate to goals and outcomes are, therefore, presently not possible. These findings lead to the discussion of a series of challenges for ACM scholarship. Opportunities remain for ACM scholars to pursue theoretical development in rigorous ways that facilitate empirically based cross-site comparisons.
\end{abstract}

Key Words: adaptive comanagement; environmental governance; systematic review

\section{INTRODUCTION}

Efforts to guide nature-society interactions, sustain ecosystem services, and improve human well-being require holistic, integrative, and multi-level institutional arrangements (Gunderson et al. 1995, Ostrom et al. 2002, Folke et al. 2005). Such arrangements are hypothesized to "... have the potential to deal with the complexity of interdependent socialecological systems (SES) and enhance the fit between ecosystem dynamics and governance systems" (Olsson et al. 2010: 263). Adaptive comanagment (ACM) has been put forward as one such promising approach (Carlsson and Berkes 2005).

Although the exact origin of the term "ACM" is unclear, it appears to have emerged in the course of a project at the Center for International Forestry Research (CIFOR) in 1997. At that time, it served to highlight the social context of adaptive management (sensu Lee 1993) but has since also come to represent an enrichment of comanagment scholarship in the directions of complexity science and resilience thinking (Plummer and Armitage 2007b). Thus, ACM combines the adaptive and collaborative narratives in resource management to engender a distinct approach. Berkes et al. (2007) synthesize the following similarities and differences between these approaches in terms of their respective focus on establishing links, temporal scope, spatial scope, and capacity building. Adaptive management focuses on learning-by-doing, takes place over the medium to long term through cycles of learning and adaptation, and concentrates on the relationships, requirements, and capacity of managers. comanagment establishes vertical institutional links, tends to produce snapshots with short to medium timeframes, bridges local level and government level(s), and is concerned with the capacity of resource users and communities. Adaptive comanagment thus forges links (both horizontal and vertical) for shared learning-by-doing between various actors, over a medium to long time horizon. It is multi-scale in spatial scope and concerned with enhancing and including the capacity of all actors with a stake for sustainably managing the resource at hand.

Today, more than 100 published items reflect the applied experiences and scholarship of ACM. Although it is not a governance panacea and must be tailored to specific contexts (Armitage et al. 2009, Berkes 2009, Plummer and Hashimoto 2011), ACM is recognized as having the potential to: address the problem of "fit" by enhancing the congruence between social institutions and biophysical systems (Olsson et al. 2007, Galaz et al. 2008); become an agent of governance that is good, right, and authentic as well as an arena in which to embrace uncertainty (Fennell et al. 2008); and, build adaptive capacity (Armitage 2007, Fabricius et al. 2007). Ultimately, ACM “... creates an 'adaptive dance' between resilience and change with the potential to sustain complex social-ecological systems" (Olsson et al. 2004:87; see also Folke et al. 2005, Berkes et al. 2007, Schultz 2009).

Reviews have been conducted to elucidate different aspects of the ACM concept (Plummer and Armitage 2007b, Plummer 2009). These have focused on synthesizing the core components of ACM (Plummer and Armitage 2007b) as well as comparing different conceptual models and identifying phases and critical variables associated with the ACM process (Plummer 2009). Although useful in drawing together the 
literature on these different topics, neither of the reviews systematically considered the entire body of ACM literature. Moreover, neither one draws on the accumulated empirical evidence to analyze the goals, components, and outcomes, or how these are linked. These shortcomings are also highlighted by Huitema et al. (2009). This paper attempts to address these gaps through a comprehensive systematic review and analysis of the ACM literature.

Given the growing body of work on ACM, there is value in systematically analyzing how the concept is being used for several reasons: to elucidate agreement but also discrepancies in how ACM is conceptualized and applied in the literature, and to examine the challenges this presents for cross-case comparisons and the possibility of arriving at more generalizable insights about how ACM contributes to improved natural resources and their governance. In an effort to achieve this, we examine the literature guided by three main objectives: (1) to broadly characterize the state of the ACM literature, (2) to enhance our understanding of how ACM is defined and operationalized, and (3) to examine how this is related to specific outcomes.

The paper is organized as follows. First, we briefly elaborate on the rationale for employing a systematic review as an analytical approach. Second, we describe the patterns emerging from our analysis. Figure 1 positions the three objectives of the paper in relation to the key analytical considerations made and offers the reader a roadmap to the presentation of results. Attention is particularly focused on the links between the stated purpose of ACM, how it is operationalized, and the outcomes this gives rise to. Third, we discuss these findings in relation to issues raised in previous reviews of ACM and reflect upon how they contribute to a more holistic understanding of ACM. We conclude by pointing out some implications for future research and practice.

\section{METHODOLOGICAL APPROACH}

Information revealed by a single case study or individual respondent can yield rich and valuable insights. However, the information necessary to infer relationships or develop theory may only be gained from a systematic comparison of a wider universe of cases and experiences. In the same way, literature reviews inevitably share the biases of social surveys and raise the challenges of formulating conclusions reached by a single review (Petticrew and Roberts 2006).

According to Thorne et al. (2004:1343), synthesis-based methodologies refer to a family of methodological approaches with the common aim of building new knowledge from a rigorous analysis of existing research findings. These methodologies are distinguishable from single reviews in the way data are collected and treated. A synthesis-based methodology is especially desirable when uncertainty or questions surround a subject where previous research has been conducted, and when an "overall picture" of evidence on a topic is useful to direct future research and methodological innovations (Petticrew and Roberts 2006). The orderly and transparent nature of such reviews permits the detection of literature omissions (Petticrew and Roberts 2006) and gaps not obvious in single studies (Crowther and Cook 2007). Although, historically, systematic reviews have tended to be quantitative in nature, qualitative systematic reviews have emerged as a similarly useful methodology (Dixon-Woods et al. 2006, Hughes et al. 2009, O'Connell and Downe 2009). For all these reasons, systematic reviews have received increasing interest and are an appropriate means to accomplish the intent of this research.

Fig. 1. Flowchart of study objectives and key analytical considerations.

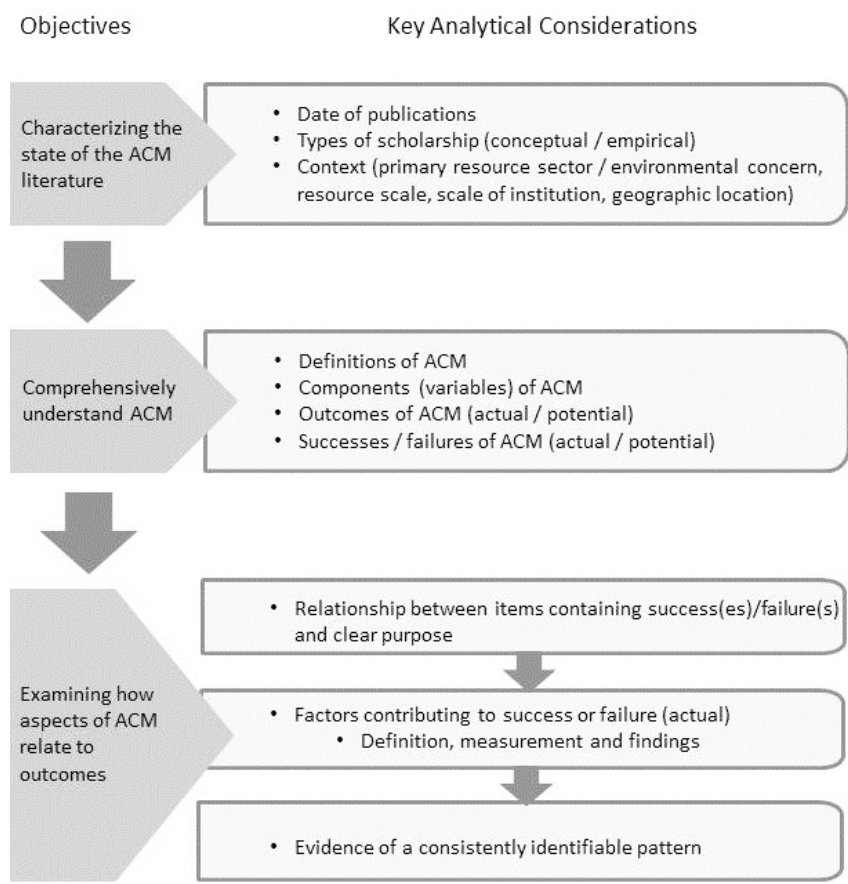

Drawing upon the literature of synthesis-based methodologies in social sciences with a qualitative orientation (Petticrew and Roberts 2006, Atkins et al. 2008, Rahimi et al. 2009), as well as the guidelines set in biological conservation (Pullin and Stewart 2006, Pullin and Knight 2009), a four-step approach was devised for the systematic review and analysis of ACM. The steps in the method are detailed in the Appendix 1, and more details on the analytical (coding) procedures undertaken to achieve each objective are described in Appendix 2. Key search terms included ecosystem or ecology* or environment* or natural resource and ACM or adaptive comanagment or adaptive collaborative management. No attempt was made by the researchers to judge or evaluate the use of these terms or labels in papers beyond the screening criteria set forth (see 
Appendix 2) because doing so would interfere with the objectives of the study. Similarly, no attempt was made by the researchers to interpret the implicit meaning of text as reported in the items. The directed screening included peer-reviewed and non-peer-reviewed items. The analysis involved an iterative process of open, axial, and selective coding to track down our objectives.

Systematic reviews and analyses are not unsusceptible to methodological challenges and have been criticized for pooling conceptually and methodologically dissimilar studies (Petticrew and Roberts 2006). The inclusion of observational studies also makes such reviews more vulnerable to bias, as these studies are more prone to bias themselves (Petticrew and Roberts 2006). Thus, it is important to acknowledge that systematic reviews ultimately reflect, and are not independent of, the quality of contributing studies (Crowther and Cook 2007). The diversity of disciplines and perspectives from which the items in this systematic review were drawn makes it imperative to also acknowledge the different interpretation of variables, outcomes, and successes. The common exclusion of unpublished data may result in the over-representation of studies with positive findings (Petticrew and Roberts 2006) and cause such reviews to miss out on potentially important insights (Dixon-Woods et al. 2006). Conversely, the inclusion of such studies may expose the systematic review to data of lesser quality (Crowther and Cook 2007). Finally, and rather unavoidably, considerable judgment is involved in reviewing data despite best efforts to achieve objectivity (Pullin and Stewart 2006). In addition to these limitations generally associated with systematic reviews, specific conditions are identified throughout the following sections to ensure accurate interpretation.

\section{CHARACTERIZING THE STATE OF THE ACM LITERATURE}

A total of 108 items (e.g., journal articles, book chapters, theses) were included in the analysis as an outcome of the search and screening criteria (see Appendix 1). Figure 2 presents the date of publication of these items and illustrates the upward trend in publication of ACM scholarship. Our first concern was to understand the nature of the types of studies being undertaken to address ACM. As it is an amalgam of different types of scholarship-ranging from conceptual to the applied-axial coding was undertaken to discern the primary orientation of each item (Appendix 2). Sixty-seven items were identified as theoretical, and 30 (of 67) items were purely conceptual and made no mention of a case. The remaining 37 also included information based on a case study. Forty-one items were identified as empirical in orientation.

Studies combining conceptual and empirical elements were the most prevalent. For example, 57 cases were included in 37 of the items identified as theoretical; only $45 \%$ of these theoretical items did not involve any case studies. Similarly, in those identified as empirical, 71 cases were included and $95 \%$ of these review items contained one or more case. The remaining $5 \%$ presented original empirical research other than a case study. In total, the systematic review revealed 128 cases of ACM, with $41 \%$ of these cases not involving the presentation of primary data. An acknowledged limitation of this analysis is that the total amount does not account for the same case appearing in multiple items. Therefore, we anticipate the total number of unique ACM cases to be fewer.

Fig. 2. Adaptive comanagement items in the systematic review by publication date.

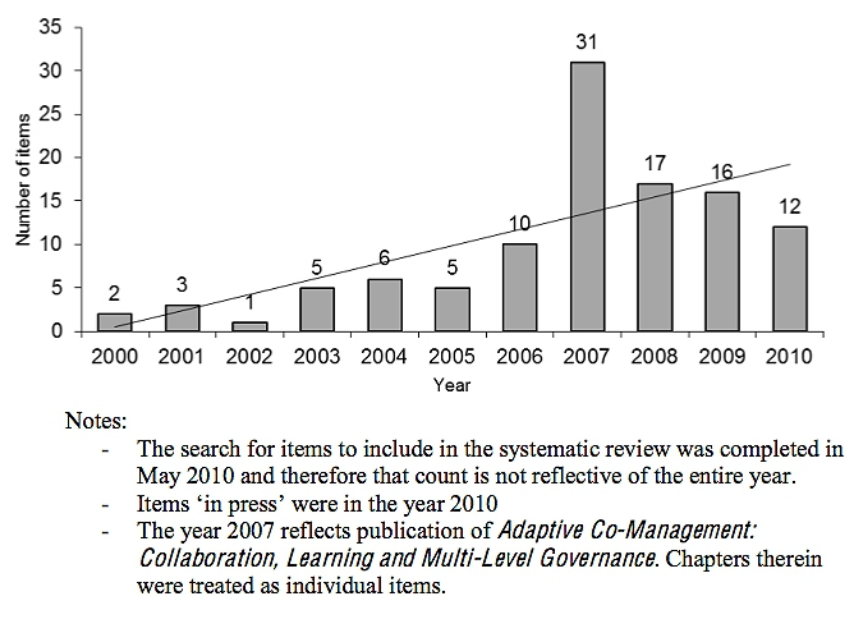

A second interest was to characterize the ACM literature according to the contexts in which ACM was being studied. Axial coding was conducted to discern several contextual considerations including the primary resource sector or environmental concern, resource scale, scale of institution, and geographic location of items reviewed. Table 1 describes these contextual elements and summarizes the findings of all the items.

Results show that ACM arrangements were studied most frequently at a regional scale, but that a local focus was also prevalent. Recognizing that the term "regional scale" and "local scale" may be interpreted differently, we use the former when the scale of the collaboration is primarily of interest to more than one geographic community and the latter when the scale of collaboration primarily concerns one geographic community. Despite these operational guides, it is valuable to note that in some situations the distinction between scales was difficult to discern. Moreover, horizontal and vertical links are inherent in ACM at both scales, and we did not attempt to discern the degree of these links. The locations in which ACM was examined most frequently were North America, Europe, and Asia. The three most frequent types of resources or environmental aspects considered were forestry, fisheries, and 
Table 1. Contextual aspects of the adaptive comanagement literature

\begin{tabular}{|c|c|c|c|c|c|c|}
\hline Contextual aspect & & Description & All items & $\begin{array}{c}\text { Cases in } \\
\text { primarily } \\
\text { theoretical } \\
\text { items }\end{array}$ & $\begin{array}{c}\text { Cases in } \\
\text { primarily } \\
\text { empirical } \\
\text { items }\end{array}$ & $\begin{array}{l}\text { Cases in all } \\
\text { items }\end{array}$ \\
\hline \multirow[t]{3}{*}{ Scale of ACM } & Regional & The collaboration is of interest to more than one community & 41 & 29 & 29 & 58 \\
\hline & Local & The collaboration concerns one community & 34 & 14 & 38 & 52 \\
\hline & Unclear & Insufficient detail was provided to discern scale & 1 & 0 & 2 & 2 \\
\hline \multirow{9}{*}{$\begin{array}{l}\text { Location and } \\
\text { sociopolitical } \\
\text { context }\end{array}$} & North America & The geographic location of the resource is North America & 24 & 17 & 15 & 32 \\
\hline & Europe & The geographic location of the resource is Europe & 20 & 11 & 13 & 24 \\
\hline & Asia & The geographic location of the resource is Asia & 18 & 14 & 15 & 29 \\
\hline & $\begin{array}{l}\text { Sub-Saharan } \\
\text { Africa }\end{array}$ & The geographic location of the resource is Sub-Saharan Africa & 12 & 5 & 15 & 20 \\
\hline & Latin America & The geographic location of the resource is Latin America & 5 & 3 & 2 & 5 \\
\hline & $\begin{array}{l}\text { Australia and } \\
\text { Oceania }\end{array}$ & $\begin{array}{l}\text { The geographic location of the resource is Australia and } \\
\text { Oceania }\end{array}$ & 3 & 2 & 2 & 4 \\
\hline & Caribbean & The geographic location of the resource is Caribbean & 1 & 0 & 4 & 4 \\
\hline & $\begin{array}{l}\text { North Africa and } \\
\text { Middle East }\end{array}$ & $\begin{array}{l}\text { The geographic location of the resource is North Africa and } \\
\text { the Middle East }\end{array}$ & 1 & 0 & 1 & 1 \\
\hline & Unclear & $\begin{array}{l}\text { Insufficient detail was provided to discern location or } \\
\text { sociopolitical context }\end{array}$ & 1 & 0 & 2 & 2 \\
\hline \multirow{11}{*}{$\begin{array}{l}\text { Type of resource } \\
\text { or aspect of } \\
\text { environment } \\
\text { considered }\end{array}$} & Forestry & Management of forests and mangroves & 17 & 12 & 15 & 27 \\
\hline & Fishery & Management of small- to large-scale fisheries & 16 & 11 & 13 & 24 \\
\hline & Water & Management of water bodies and resources & 13 & 13 & 7 & 20 \\
\hline & Wildlife & Management of terrestrial and aquatic creatures & 10 & 3 & 10 & 13 \\
\hline & Wetland & Wetland landscapes (e.g., Kristianstads Vattenrike) & 9 & 7 & 5 & 12 \\
\hline & Protected area & Management of parks and protected areas & 8 & 7 & 3 & 10 \\
\hline & Multiple & $\begin{array}{l}\text { Multiple resources are addressed without discernable } \\
\text { emphasis on one }\end{array}$ & 4 & 1 & 7 & 8 \\
\hline & $\begin{array}{l}\text { Land } \\
\text { management }\end{array}$ & Management of land uses; other resource not specified & 3 & 0 & 6 & 6 \\
\hline & Coastal & Management of coasts and coral reefs & 2 & 1 & 1 & 2 \\
\hline & Agriculture & Management of agriculture & 2 & 1 & 1 & 2 \\
\hline & $\begin{array}{l}\text { Community } \\
\text { justice }\end{array}$ & Environmental justice & 1 & 0 & 1 & 1 \\
\hline \multirow{3}{*}{$\begin{array}{l}\text { Scale of } \\
\text { resource or } \\
\text { aspect of } \\
\text { environment } \\
\text { considered }\end{array}$} & Regional & The resource concern is beyond one community & 39 & 29 & 34 & 63 \\
\hline & Local & The resource concerns one community & 33 & 13 & 33 & 46 \\
\hline & Unclear & $\begin{array}{l}\text { Insufficient detail was provided to discern scale of resource or } \\
\text { aspect of environment considered }\end{array}$ & 1 & 0 & 2 & 2 \\
\hline
\end{tabular}

N.B. The term "case" within the primarily theoretical items is used to capture the presence of an in-depth focus on a particular topic or the presentation of one or more particular studies. For example, the item may be primarily theoretical in orientation and, within it, specifically apply concepts to forestry in North America or present a case study of forestry in Oregon to illustrate the conceptual investigation. The term "case" within the primarily empirical items is used to capture the presence of a particular in-depth study or studies within the item. For example, one empirical item may present three in-depth studies on agriculture in different places. Therefore, the term "case" as used here reflects considerable breadth. 
water resources, and the scales at which these were investigated both regionally and locally were well represented.

It is important to recognize the variable nature of the case material presented in the items. For example, in some items, the case involved a general sector or resource (e.g., forestry), whereas in others, it may have involved both a sector and specific location (e.g., forestry in Indonesia). Consequently, the numbers of cases identified for the contextual aspects do not necessarily equal the total number of case studies identified. Another caveat here is that a broad and inclusive definition of case study was employed. It is acknowledged that using such a term conceals great variability, especially insofar as some case material was brief and others were more robust and conveyed greater depth. Nonetheless, the broad pattern reveals that studies usually combine conceptual and empirical elements, involve one or more cases, are examined in North America, Europe, and Asia, and consider forestry, fisheries, water, wildlife, wetlands, and protected areas.

\section{UNPACKING ACM FROM ACCUMULATED EXPERIENCES}

Our second objective sought to comprehensively understand ACM based on experiences accumulated to date, and our third objective aimed to examine how aspects of ACM relate to outcomes. Specific questions corresponding to these objectives were developed in step one of the systematic review (see Appendix 1) and are used here as sub-headings to unpack ACM from accumulated experiences. Figure 1 also offers a structural guide to the presentation of the results.

\section{How is ACM Defined?}

A key issue in being able to compare ACM processes across cases to discern patterns in what contributes to success or failure is that the concept under study is well, and consistently, defined. A logical starting point, therefore, was to examine how the purpose(s) of ACM-i.e., the aims, goals, and intentions of ACM-were defined across our surveyed items (Appendix 2).

Two major themes emerged from the analysis. The first, combining the learning aspect of adaptive management with the linking function of collaboration, was the most frequently cited purpose (25 items, 42 passages) of ACM. Equally frequent was the expression of ACM as encompassing collaboration, the capacity to adapt, and some additional aspect (25 items, 37 passages). The additional aspects contained herein were widespread and included knowledge, resilience, enhanced management and governance, improved human well-being, enhanced communication, and policy innovation.

A number of additional purposes of ACM emerged beyond the two main themes. These themes were less concerned with joining learning and linking functions. Among these themes were statements referring only to the capacity to adapt (18 items, 23 passages), only to collaboration (four items, four passages) or only to one of these and one "other" (e.g., sustainability, resilience, revision of institutions, and knowledge). Moreover, themes also conveyed the intended consequence without relating it to adaptive capacity or collaboration (nine items, 10 passages). These consequences included sustainability, improved human well-being, and resilience. Illustrative of this theme are Charles's (2007:83) remarks: "the premise here is that desirable resource management policies and practices-in this case, those relating to ACM-are those that enhance the sustainability and resilience needed in any 'healthy' resource system."

Further analysis of the relationship among themes reveals the extent to which purposes of ACM are multi-tiered and multifaceted. A general pattern can be discerned where studies of ACM appear to cluster along two axes: those primarily concerned with fostering capacity for adaptation and encouraging the development of connections through collaboration; and those also explicitly concerned with ACM as means to bring about a number of desirable changes through adaptation and collaboration associated with discourses on social-ecological resilience (sensu Folke (2006)) and sustainability. These aims are not mutually exclusive, as evidenced by the numerous minor themes that connect them in various ways. Finally, it is interesting and thought provoking to note that our analysis shows that $46 \%$ of items did not convey any purpose of ACM. Although speculative, we wonder if this relatively high degree of items is due to an assumption of implicit intent when employing the term ACM. Moreover, a similar assumption may explain the additional purposes of ACM that were revealed and do not include the joining of adaptation and collaboration.

\section{What Components (Variables) of ACM Are Garnering Attention?}

As experience with ACM grows, scholars and practitioners are exploring and examining an increasing range of variables that are believed to be critical components of the ACM process. Analysis identified 12 variables receiving particular attention by ACM scholars. As illustrated in Fig. 3, they range considerably in the amount of focus they receive. The five most commonly focused on include learning, knowledge, networks, shared power, and organizational interactions.

Table 2 briefly describes each variable and identifies associated themes. For the three most prevalent categories (learning, knowledge, networks), the breadth and depth of the emerging themes are pronounced. Learning, for example, exhibits the sub-theme of social learning and emerged in 81 items and 400 passages. Although it is beyond the scope of this paper to identify the extensive number of themes within each category, social learning should be highlighted for appearing in more items than some of the main variables (for 
Table 2. Component or variables of interest emerging within adaptive comanagement

\begin{tabular}{|c|c|c|c|}
\hline $\begin{array}{l}\text { Component or } \\
\text { Variable }\end{array}$ & Description & $\begin{array}{l}\text { No. of } \\
\text { Items }\end{array}$ & No. of Passages \\
\hline $\begin{array}{l}\text { Bridging } \\
\text { Organizations }\end{array}$ & $\begin{array}{l}\text { Bridging organizations/institutions are intermediaries (not individuals), and attention in this } \\
\text { theme is on the role played by these bodies. Attention is given to how they support interface } \\
\text { with other variables (e.g., learning, trust, networks, linkages) and catalyze ACM. Functions } \\
\text { of "boundary organizations" or "brokering organizations" are included. }\end{array}$ & 19 & 57 \\
\hline Conflict & $\begin{array}{l}\text { Conflict encompasses tensions arising between/among the individuals and organizations in } \\
\text { ACM. Sub-themes include: conflict resolution, mechanisms to resolve conflicts, } \\
\text { opportunities associated with conflicts. }\end{array}$ & 40 & 79 \\
\hline $\begin{array}{l}\text { Enabling } \\
\text { Conditions }\end{array}$ & $\begin{array}{l}\text { Enabling conditions include circumstances central to developing and/or sustaining the ACM } \\
\text { process. Sub-themes include: legislation or policy, the role of government, funding. Myriad } \\
\text { other conditions emerged within the sub-theme "other," with many referring to other } \\
\text { variables. }\end{array}$ & 42 & 89 \\
\hline Incentives & $\begin{array}{l}\text { Incentives encompass things that incite, sustain, or truncate ACM. The general notion of } \\
\text { incentives is identified as being important to ACM and as an unconditional catalyst (both } \\
\text { monetary and non-monetary). Additional sub-themes focus on rewards and punishments } \\
\text { contingent on specific achievements/behaviors. }\end{array}$ & 21 & 35 \\
\hline Knowledge & $\begin{array}{l}\text { The information/skills/expertise/experiences/worldviews that individuals and organizations } \\
\text { bring to ACM and their associated uses and influences are encapsulated in the theme } \\
\text { knowledge. Numerous sub-themes emerged in association with knowledge, such as: } \\
\text { combination of knowledge, types of knowledge, information forms and functions, } \\
\text { communication of knowledge, control of knowledge, and knowledge in relation to other } \\
\text { variables. }\end{array}$ & 83 & 344 \\
\hline Leadership & $\begin{array}{l}\text { The act of leading or emergence of guiding (by an individual or organization) emerged as } \\
\text { the theme of leadership. Its presence or absence was typically connected with the success or } \\
\text { failure of ACM and key associated characteristics discussed. }\end{array}$ & 39 & 116 \\
\hline Learning & $\begin{array}{l}\text { Learning broadly concerns how knowledge is gained and employed in relation to ACM. } \\
\text { Attention is also given to the influence of the learning process on ACM as well as its } \\
\text { interaction with other variables. The sub-theme of social learning emerges with considerable } \\
\text { strength ( } 81 \text { items, } 400 \text { passages). Other sub-themes include: experiential learning, } \\
\text { monitoring and evaluation, and transformative learning. }\end{array}$ & 94 & 687 \\
\hline Networks & $\begin{array}{l}\text { Networks capture the connections (structurally and functionally) between and among the } \\
\text { entities, and the theme emerges frequently as being important to ACM. Sub-themes include } \\
\text { the features of networks (e.g., cross-scale, multi-level), the type of networks (e.g., formal, } \\
\text { informal), and relationship to other variables (e.g., social capital, learning, knowledge). }\end{array}$ & 69 & 325 \\
\hline $\begin{array}{l}\text { Organizational } \\
\text { Interactions }\end{array}$ & $\begin{array}{l}\text { Organizational interactions consider links between and among organizations (formal and } \\
\text { informal). Sub-themes include: the nature of these links (horizontal and vertical), the extent } \\
\text { to which they cross scales and levels, the fit with ecosystems, and their consequences (e.g., } \\
\text { enhance fit). }\end{array}$ & 64 & 206 \\
\hline Shared Power & $\begin{array}{l}\text { Shared power is a foundational premise of ACM and often considered a structural element. } \\
\text { The theme is often employed in a general sense to convey the collective ability to influence } \\
\text { or exert authority. Sub-themes include: empowerment, devolution of power } \\
\text { (decentralization), and emphasis on property rights. }\end{array}$ & 54 & 234 \\
\hline $\begin{array}{l}\text { Shared } \\
\text { Responsibility }\end{array}$ & $\begin{array}{l}\text { Shared responsibility refers to the collective sharing of obligations for a resource or } \\
\text { environmental consideration. Incorporation of rights and transfer of responsibilities are } \\
\text { common considerations. }\end{array}$ & 33 & 74 \\
\hline Trust & $\begin{array}{l}\text { Trust focuses on the relationship between and among people. Trust is considered as a key } \\
\text { influence on success or failure of ACM. It is examined within case studies and highlighted } \\
\text { as a critical link in building cross-scale and cross-level links. }\end{array}$ & 49 & 126 \\
\hline
\end{tabular}

example, bridging organizations, incentives). It refers to learning that occurs through human interactions and as a process of iterative reflection (often characterized by multiple loops) and has received intense consideration within the ACM literature.

\section{What Outcomes of ACM Are Being Realized?}

Adaptive comanagment is instrumental in nature, and those engaging with the concept do so with the underlying premise that the process will lead to some type of outcome. Our analysis revealed 60 distinct themes representing outcomes in 196 passages, across 61 items. The outcomes of ACM as revealed by the systematic review are categorized as "actual" or "potential" and are presented in Tables 3 and 4. The "actual" category encompasses passages based on direct substantiated observations or experiences as well as statements of causal assertion. The "potential" category refers to passages of text that are speculative or anticipatory in nature, offering 
outcomes theorized or anticipated by the authors. In total, 44 actual outcomes emerged from 22 items. Conflict resolution was the most frequent actual outcome of ACM. The potential category revealed 41 outcomes of ACM from 52 items. The development of adaptive capacity emerged clearly as the potential outcome with the greatest frequency.

Fig. 3. Component or variables of interest emerging within adaptive comanagement.

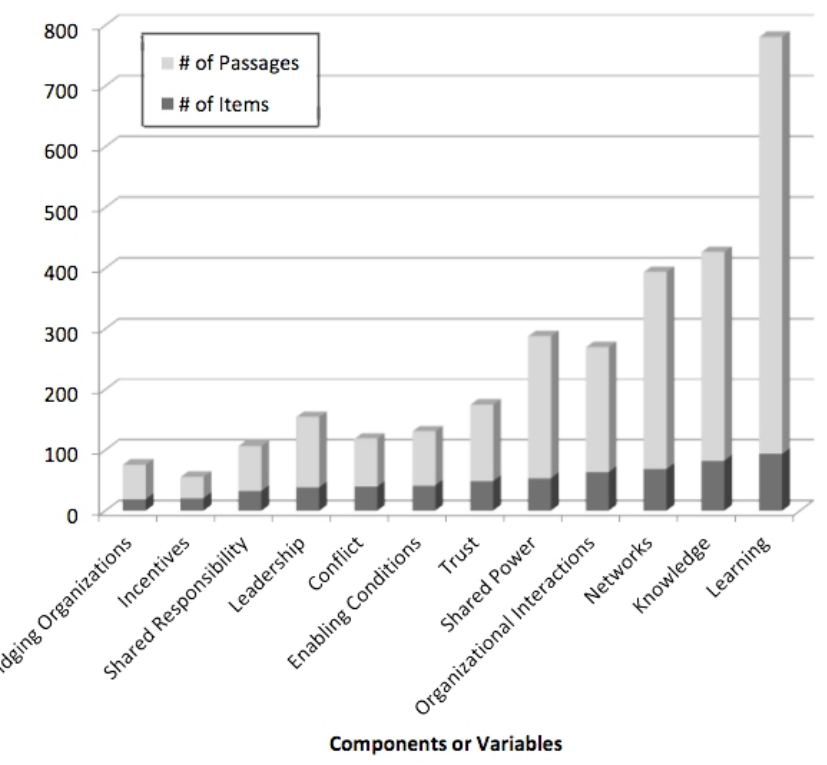

Comparing the categories of "actual" and "potential" outcomes reveals several similarities and differences. Both encompass a relatively long list of outcomes, and the frequency of mention of many of these is low (fewer than two items and fewer than three passages). Within the five outcomes with the greatest strength (i.e., highest frequency of number of items and passages), the development of adaptive capacity is the only one to occur in both themes. In broadening consideration to all the outcomes that emerged, 18 were identified as both potential and actual. Analysis also reveals that eight outcomes that emerged appear contradictory. We use the term "appear contradictory" to refer to instances where outcomes seem to be in opposition and stress that all systematic reviews are limited by the reporting in the different items that are analyzed. Examples of such contradictory outcomes include: resolution of conflict or dispute vs. temporary increase in explicit conflict; increased resource health vs. reduced resource health; increased equity in distribution of benefits and costs vs. unequal distribution of benefits). In all instances of these contradictions, the strength was low (fewer than two items and fewer than three passages). The presence of such contradictions suggests that the outcomes of ACM are not always straightforward. In the potential category, there appears to be a clear demarcation point between the six outcomes with the greatest strength (eight or more items and
15 or more passages) and the remainder (five or fewer items and seven or fewer passages). A similar demarcation point is not evident in the actual outcomes that emerged. This suggests that when authors hypothesize around outcomes, they tend to

Table 3. Actual outcomes of adaptive comanagement

\begin{tabular}{|c|c|c|}
\hline Description & Number of Items & $\begin{array}{c}\text { Number of } \\
\text { Passages }\end{array}$ \\
\hline Resolution of conflict or dispute & 8 & 17 \\
\hline $\begin{array}{l}\text { Increased participation by or } \\
\text { engagement of marginalized } \\
\text { stakeholders }\end{array}$ & 4 & 15 \\
\hline Development of adaptive capacity & 7 & 13 \\
\hline Increased collaboration & 4 & 12 \\
\hline Economic development & 3 & 10 \\
\hline $\begin{array}{l}\text { Enhanced communication and } \\
\text { negotiation }\end{array}$ & 3 & 10 \\
\hline Devolution of power & 2 & 10 \\
\hline Improved resource health & 7 & 9 \\
\hline Achievement of developmental goals & 3 & 9 \\
\hline $\begin{array}{l}\text { Increased interest or investment in } \\
\text { resource health }\end{array}$ & 3 & 8 \\
\hline Enhanced livelihoods & 3 & 8 \\
\hline Relationships of trust & 1 & 8 \\
\hline Reduced power imbalances & 2 & 8 \\
\hline $\begin{array}{l}\text { Generation, sharing, and integration of } \\
\text { knowledge }\end{array}$ & 6 & 8 \\
\hline $\begin{array}{l}\text { Increased accountability and } \\
\text { transparency }\end{array}$ & 2 & 8 \\
\hline $\begin{array}{l}\text { Increased self-confidence and skills } \\
\text { among locals }\end{array}$ & 3 & 8 \\
\hline $\begin{array}{l}\text { New or modified institutional } \\
\text { arrangements }\end{array}$ & 4 & 8 \\
\hline Learning & 6 & 7 \\
\hline Changes in perceptions and actions & 2 & 7 \\
\hline $\begin{array}{l}\text { Enhanced efficiency and effectiveness } \\
\text { of management }\end{array}$ & 5 & 7 \\
\hline Creative ideas for solving problems & 5 & 6 \\
\hline Decrease in illegal resource use & 3 & 6 \\
\hline Social-ecological resilience & 3 & 4 \\
\hline Development of networks & 4 & 4 \\
\hline $\begin{array}{l}\text { Increased equity in distribution of costs } \\
\text { and benefits }\end{array}$ & 1 & 4 \\
\hline $\begin{array}{l}\text { Broader based legitimization for } \\
\text { management }\end{array}$ & 3 & 4 \\
\hline Unequal distribution of benefits & 2 & 3 \\
\hline Increased well-being & 3 & 3 \\
\hline Resource management plans & 2 & 3 \\
\hline Failure to improve livelihoods & 2 & 2 \\
\hline Empowerment of stakeholders & 2 & 2 \\
\hline Improved access to resources & 1 & 2 \\
\hline Failed institutionalization of attitudes & 1 & 1 \\
\hline Community development & 1 & 1 \\
\hline Animosity from government & 1 & 1 \\
\hline Failure to lessen state control & 1 & 1 \\
\hline $\begin{array}{l}\text { Absent empowerment through material } \\
\text { gains }\end{array}$ & 1 & 1 \\
\hline Changes in environmental parameters & 1 & 1 \\
\hline Strengthened institutions & 1 & 1 \\
\hline No changes in resource condition & 1 & 1 \\
\hline Increases in supporting mechanisms & 1 & 1 \\
\hline Temporary increase in explicit conflict & 1 & 1 \\
\hline Increased transaction costs (time) & 1 & 1 \\
\hline Proliferation of illegal activities & 1 & 1 \\
\hline
\end{tabular}


range within a much narrower scope than the diversity found in reality.

\section{Is ACM a Success?}

The opening paragraphs of this paper allude to the positive expectations (or potentiality) associated with ACM. Our query sought to take stock of the successes and failures of ACM by systematically analyzing all 108 items. A total of 17 items in the systematic review contained information about the success of ACM in 28 passages. Similar to the outcomes, specific success was found to be treated in two ways, as an observable phenomenon directly linked to the ACM process or as an anticipated outcome. Therefore, we used a similar system of categorization for success, distinguishing between "actual success" and "potential success" in the items reviewed.

Table 5 lists the successes identified from coding within each respective category (actual and potential). Within each category, eight specific successes were identified. Participation and involvement of relevant stakeholders was the actually observed success of ACM with the greatest cumulative number of mentions. An example is illustrated by (Ayles et al. 2007:137): “...the success of the plan, as exhibited not just by the recovery of the char stock but also by the community support it garnered, is a matter of pride for the working group and the Paulatuk HTC. It is viewed as a success for comanagment in the wider ISR community, and in 2003, the working group members received the FJMC comanagment Award for their contribution to comanagment in the Arctic. A further result is that community members are ready to take greater personal responsibility for the management of their resources."

Conflict resolution and collaboration were the only successes to appear as both actual and potential.

Twenty of the items addressed failure, lack of success, and/or undesirable consequences of ACM. The categories "actual failure" and "potential failure" were again useful to differentiate those with and without an empirical basis. Table 6 presents the 12 actual failures and the 11 potential failures associated with ACM. Failure to achieve sustainable resource use or social-ecological resilience is the specific actual failure with the greatest strength (eight items and eight passages). For example, Fabricius and Cundill (2010:60-61) observed that "despite the existence of a window of opportunity, and the benefits of adaptive comanagment coupled with several decades' experience working in rural African communities in community-based natural resource management setting, things still went wrong. Since there was no structure to report to, the Village Land Committees, while continuing to exist, have not progressed further than developing the mini management plans, with negative implications for monitoring, institutions and, ultimately, ecosystem resilience." Comparative analysis of the actual and potential categories reveals considerable overlap, as nine specific failures appear in both.
Table 4. Potential outcomes of adaptive comanagement

\begin{tabular}{|c|c|c|}
\hline Description & Number of Items & $\begin{array}{c}\text { Number of } \\
\text { Passages }\end{array}$ \\
\hline Development of adaptive capacity & 24 & 36 \\
\hline Social-ecological resilience & 18 & 25 \\
\hline Sustainable resource use & 16 & 21 \\
\hline $\begin{array}{l}\text { Enhanced efficiency and } \\
\text { effectiveness of management }\end{array}$ & 17 & 20 \\
\hline Enhanced livelihoods & 8 & 15 \\
\hline Creative ideas for solving problems & 8 & 15 \\
\hline Devolution of power & 5 & 7 \\
\hline Increased collaboration & 6 & 6 \\
\hline $\begin{array}{l}\text { Broader-based legitimization for } \\
\text { management }\end{array}$ & 5 & 6 \\
\hline $\begin{array}{l}\text { Enhanced communication and } \\
\text { negotiations }\end{array}$ & 4 & 5 \\
\hline Resolution of conflict & 5 & 5 \\
\hline $\begin{array}{l}\text { Increased participation and } \\
\text { engagement by stakeholders or } \\
\text { participatory decision making }\end{array}$ & 5 & 5 \\
\hline Increased income & 4 & 4 \\
\hline Increased equity in decision making & 4 & 4 \\
\hline $\begin{array}{l}\text { Increased equity in distribution of } \\
\text { benefits and costs }\end{array}$ & 3 & 4 \\
\hline $\begin{array}{l}\text { Increased self-confidence and skills } \\
\text { of locals }\end{array}$ & 4 & 4 \\
\hline $\begin{array}{l}\text { Increased awareness of challenges } \\
\text { and current flaws and resource } \\
\text { health }\end{array}$ & 4 & 4 \\
\hline Increased resource health & 3 & 4 \\
\hline Changes in perceptions and actions & 3 & 3 \\
\hline $\begin{array}{l}\text { Increased equity in access to } \\
\text { resource }\end{array}$ & 3 & 3 \\
\hline $\begin{array}{l}\text { New or modified institutional } \\
\text { arrangements }\end{array}$ & 3 & 3 \\
\hline $\begin{array}{l}\text { Improvements in human and social } \\
\text { capital }\end{array}$ & 2 & 2 \\
\hline $\begin{array}{l}\text { Better defined rights and } \\
\text { responsibilities }\end{array}$ & 2 & 2 \\
\hline Reduced vulnerability & 2 & 2 \\
\hline Linking of knowledge & 2 & 2 \\
\hline Reduced transaction costs & 1 & 1 \\
\hline Reduced resource health & 1 & 1 \\
\hline Illegitimate decisions & 1 & 1 \\
\hline $\begin{array}{l}\text { Creation of conditions for } \\
\text { management }\end{array}$ & 1 & 1 \\
\hline Increased capacity in community & 1 & 1 \\
\hline $\begin{array}{l}\text { Promotion of social and cultural } \\
\text { values }\end{array}$ & 1 & 1 \\
\hline Overcome capacity challenges & 1 & 1 \\
\hline $\begin{array}{l}\text { Modification of unsustainable } \\
\text { social-ecological feedbacks }\end{array}$ & 1 & 1 \\
\hline $\begin{array}{l}\text { Increase in protectionist practices } \\
\text { that disadvantage vulnerable users }\end{array}$ & 1 & 1 \\
\hline Agreed-upon sanctions & 1 & 1 \\
\hline $\begin{array}{l}\text { New cooperative undertakings } \\
\text { beyond specific issue }\end{array}$ & 1 & 1 \\
\hline Building of memory & 1 & 1 \\
\hline Strengthened institutions & 1 & 1 \\
\hline Community cohesion & 1 & 1 \\
\hline Resource management plans & 1 & 1 \\
\hline
\end{tabular}


However, $75 \%$ of the specific failures across both categories emerged with relatively little strength (fewer than two items and fewer than two passages).

Table 5. Successes of adaptive comanagement

\begin{tabular}{lcc}
\hline \hline Description & $\begin{array}{c}\text { Number } \\
\text { of } \\
\text { Items }\end{array}$ & $\begin{array}{c}\text { Number } \\
\text { of } \\
\text { Passa- } \\
\text { ges }\end{array}$ \\
\hline Actual & $\mathbf{9}$ & $\mathbf{1 7}$ \\
Participation and involvement of relevant stakeholders & 6 & 10 \\
Conflict resolution & 3 & 7 \\
Improved resource health & 4 & 4 \\
Collaboration & 3 & 3 \\
Education & 2 & 2 \\
Improved community well-being & 2 & 2 \\
Transformation of institutions & 1 & 1 \\
Improved communication & 1 & 1 \\
Potential & $\mathbf{9}$ & $\mathbf{1 1}$ \\
Collaboration & 6 & 6 \\
Conflict resolution & 4 & 5 \\
Empowerment & 3 & 4 \\
Equitable distribution of resources & 3 & 3 \\
More efficient and effective decision making & 3 & 3 \\
Learning & 2 & 3 \\
Enhanced credibility and legitimization & 2 & 2 \\
Flexibility and adaptation of institutions & 1 & 1 \\
\hline
\end{tabular}

In attempting to appraise the achievements of ACM, the review compares the empirical (i.e., actual) evidence on successes and failures of ACM accumulated thus far. Acknowledged limitations in making this comparison are that the labels of success and failure are variously defined by authors and also vary considerably in scope. Notwithstanding this caveat, there are eight themes of actual success and 12 themes of actual failure from experience thus far. Of all the themes, failure to achieve sustainable resource use or socialecological resilience emerged with the greatest frequency (eight items, eight passages). Moreover, four themes appear in both the success and the failure categories, signaling that the associated results of ACM are mixed thus far. These include: resource health/achievement of sustainable resource use or social-ecological resilience; participation and involvement of relevant stakeholders/ failure to facilitate pluralism and linkages, community well-being, and conflict.

\section{Can Insights Be Drawn as to How Aspects of ACM Relate to Outcomes?}

Our third objective sought to examine how aspects of ACM relate to outcomes of ACM processes. To do this, we first analyzed the relationship between items containing information on successes and failures and the presence of a clear purpose of ACM. We then focused on identifying the factors that contribute to the success or failure of ACM. By factors, we refer both to the key variables or components associated with ACM in the reviewed literature (Table 2), as well as other, potentially contextual, factors, such as research and practical experience, ecological disturbances, and presence of crisis. Finally, we examined the definition, measurement, and findings associated with the factors across the items in which it was found. We then determined the presence or absence of a consistent pattern from which robust conclusions may be drawn.

Given the criticality of clearly and consistently defining ACM in making comparisons and establishing patterns, we probed the relationship between the items containing information on successes and failures and the extent to which a clear purpose of ACM was also conveyed. Fifty-four percent of all items containing information on successes and failures of ACM also conveyed a clear purpose. A difference between the failure and success categories is evident, as $60 \%$ of those items in the former category also had a clear purpose of ACM, whereas only $47 \%$ of items in the latter category did. These results are concerning as the absence of clear purpose/definition (as well as diversity of definitions identified above) hinders the ability to evaluate outcomes.

Table 6. Failures of adaptive comanagement

\begin{tabular}{|c|c|c|}
\hline Description & $\begin{array}{l}\text { Number } \\
\text { of Items }\end{array}$ & $\begin{array}{c}\text { Number of } \\
\text { Passages }\end{array}$ \\
\hline Actual & 15 & 19 \\
\hline $\begin{array}{l}\text { Failure to achieve sustainable resource use or } \\
\text { social-ecological resilience }\end{array}$ & 8 & 8 \\
\hline Failure to facilitate pluralism and links & 5 & 5 \\
\hline $\begin{array}{l}\text { Failure to enhance legitimization for policies and } \\
\text { actions }\end{array}$ & 2 & 2 \\
\hline Failure to enhance equity in resource sharing & 2 & 2 \\
\hline Failure to increase income & 2 & 2 \\
\hline Failure to increase community well-being & 2 & 2 \\
\hline $\begin{array}{l}\text { Failure to enhance equity and efficiency of } \\
\text { decision making }\end{array}$ & 1 & 1 \\
\hline Failure to enhance livelihoods of locals & 1 & 1 \\
\hline Failure to change perceptions and actions & 1 & 1 \\
\hline Unequal distribution of costs and benefit & 1 & 1 \\
\hline Failure to resolve conflict & 1 & 1 \\
\hline Demoralization & 1 & 1 \\
\hline Potential & 9 & 13 \\
\hline Failure to facilitate pluralism and links & 6 & 6 \\
\hline $\begin{array}{l}\text { Failure to enhance equity and efficiency of } \\
\text { decision making }\end{array}$ & 4 & 4 \\
\hline Failure to resolve conflict & 2 & 3 \\
\hline Failure to enhance equity in resource sharing & 3 & 3 \\
\hline $\begin{array}{l}\text { Failure to achieve sustainable resource use or } \\
\text { social-ecological resilience }\end{array}$ & 2 & 2 \\
\hline $\begin{array}{l}\text { Failure to enhance legitimization for policies and } \\
\text { actions }\end{array}$ & 2 & 2 \\
\hline Deterioration of resource management plans & 2 & 2 \\
\hline Failure to enhance adaptive capacity & 1 & 1 \\
\hline Failure to enhance livelihoods of locals & 1 & 1 \\
\hline Unequal distribution of costs and benefits & 1 & 1 \\
\hline Failure to decrease poverty & 1 & 1 \\
\hline
\end{tabular}


Factors contributing to success and failure receive a strong focus within the ACM literature. Similar to the analysis of successes and failures above, these factors were categorized according to their "actual" (i.e., from experience) or "potential" (i.e., anticipatory) nature. Seventy-five passages, across 38 items, contained information on factors contributing to the success of ACM (Table 7). Social networks was the "actual" factor most frequently documented, cited almost twice as many times as the second strongest theme, which was learning. Five themes (social networks; learning; participation of relevant stakeholders in management; generation, use and sharing of information and knowledge; management flexibility) appeared in both the actual and potential categories. The number of factors identified as potentially contributing to successful ACM is almost double the number that emerged from actual experience.

Table 7. Factors contributing to success of adaptive comanagement

\begin{tabular}{|c|c|c|}
\hline Description & $\begin{array}{l}\text { Number } \\
\text { of } \\
\text { Items }\end{array}$ & $\begin{array}{l}\text { Number } \\
\text { of } \\
\text { Passages }\end{array}$ \\
\hline$\overline{\text { Actual }}$ & 17 & 31 \\
\hline Social networks & 13 & 18 \\
\hline Learning & 8 & 16 \\
\hline $\begin{array}{l}\text { Participation of all relevant stakeholders in } \\
\text { management }\end{array}$ & 5 & 6 \\
\hline $\begin{array}{l}\text { Generation, use, and sharing of information and } \\
\text { knowledge }\end{array}$ & 3 & 4 \\
\hline Development of necessary attitudes and skills & 2 & 2 \\
\hline Government control over illegal resource use & 1 & 1 \\
\hline Management flexibility & 1 & 1 \\
\hline Funding & 1 & 1 \\
\hline Potential & 29 & 44 \\
\hline Participation of relevant stakeholders in management & 14 & 16 \\
\hline Social networks & 13 & 14 \\
\hline Learning & 11 & 16 \\
\hline Enforcement of rules & 11 & 12 \\
\hline $\begin{array}{l}\text { Generation, use, and sharing of information and } \\
\text { knowledge }\end{array}$ & 9 & 11 \\
\hline Management flexibility & 6 & 6 \\
\hline Conflict resolution & 4 & 4 \\
\hline Shared vision & 4 & 4 \\
\hline Long-term commitment & 3 & 3 \\
\hline Access to resources (information, funding, etc.) & 2 & 2 \\
\hline Leadership & 2 & 2 \\
\hline Clearly defined resource system & 2 & 2 \\
\hline Self-organization & 1 & 1 \\
\hline Institutional design principles & 1 & 1 \\
\hline Research and practical experience & 1 & 1 \\
\hline Management efficiency & 1 & 1 \\
\hline Presence of crisis & 1 & 1 \\
\hline Small-scale contexts & 1 & 1 \\
\hline
\end{tabular}

Forty-eight passages, across 24 items, address factors (actual and potential) contributing to failure of ACM (Table 8). The number of potential factors contributing to ACM failure was again greater than the number of actual ones, although the degree of congruence was substantial, with 14 themes occurring in both.

Table 8. Factors Contributing to Failures of Adaptive Comanagement

\begin{tabular}{|c|c|c|}
\hline Description & $\begin{array}{c}\text { Number } \\
\text { of } \\
\text { Items }\end{array}$ & $\begin{array}{l}\text { Number } \\
\text { of } \\
\text { Passages }\end{array}$ \\
\hline Actual & 16 & 24 \\
\hline Conflict of interests of those involved & 7 & 8 \\
\hline Power asymmetries among those involved & 4 & 8 \\
\hline $\begin{array}{l}\text { Insufficient resources (financial, human, technical, } \\
\text { etc.) }\end{array}$ & 4 & 5 \\
\hline Restrictive policies or institutions & 3 & 3 \\
\hline Absence of multi-stakeholder commitment & 2 & 3 \\
\hline $\begin{array}{l}\text { Deficiencies/inconsistencies in communication, } \\
\text { information, knowledge }\end{array}$ & 3 & 3 \\
\hline Unclear privileges, guidelines, and responsibilities & 2 & 2 \\
\hline Short-term outlook & 2 & 2 \\
\hline $\begin{array}{l}\text { Inability to learn, adapt, problem solve, or self- } \\
\text { organize }\end{array}$ & 2 & 2 \\
\hline Lack of leadership & 1 & 1 \\
\hline Lack of understanding of ACM process & 1 & 1 \\
\hline Ecological disturbances & 1 & 1 \\
\hline Absence of social networks & 1 & 1 \\
\hline $\begin{array}{l}\text { Inability to make decisions, problems with decision- } \\
\text { making process }\end{array}$ & 1 & 1 \\
\hline Poorly developed civil society & 1 & 1 \\
\hline $\begin{array}{l}\text { Lack of homogeneity among resource systems and } \\
\text { users }\end{array}$ & 1 & 1 \\
\hline Potential & 16 & 27 \\
\hline Conflict of interests of those involved & 7 & 12 \\
\hline $\begin{array}{l}\text { Inability to learn, adapt, problem solve, or self- } \\
\text { organize }\end{array}$ & 7 & 8 \\
\hline Restrictive policies or institutions & 5 & 5 \\
\hline Lack of legitimate representation of stakeholders & 5 & 5 \\
\hline $\begin{array}{l}\text { Insufficient resources (financial, human, technical, } \\
\text { etc.) }\end{array}$ & 3 & 3 \\
\hline Power asymmetries among those involved & 2 & 2 \\
\hline Unclear privileges, guidelines, and responsibilities & 2 & 2 \\
\hline Short-term outlook & 2 & 2 \\
\hline $\begin{array}{l}\text { Deficiencies/inconsistencies in communication, } \\
\text { knowledge, information }\end{array}$ & 2 & 2 \\
\hline $\begin{array}{l}\text { Inability to make decisions, problems with decision- } \\
\text { making process }\end{array}$ & 2 & 2 \\
\hline Defensiveness & 1 & 1 \\
\hline Absence of multi-stakeholder commitment & 1 & 1 \\
\hline Inadequate amount of time for ACM to develop & 1 & 1 \\
\hline Lack of leadership & 1 & 1 \\
\hline Lack of understanding of ACM process & 1 & 1 \\
\hline Ecological disturbances & 1 & 1 \\
\hline Absence of social networks & 1 & 1 \\
\hline Problem of fit between ecosystem and institution & 1 & 1 \\
\hline Unbalanced approach to ethics & 1 & 1 \\
\hline Misconstruing effectiveness for success & 1 & 1 \\
\hline Failure to seize windows of opportunity & 1 & 1 \\
\hline
\end{tabular}

In comparing the factors (actual and potential) contributing to success and those contributing to failure of ACM, a total of eight themes emerged in common (i.e., positive attributes of the factor contributed to success and negative attributes 
contributed to failure). These include: conflict; resources; policies and institutions; stakeholder participation/commitment; communication, information, knowledge; learning, adaptation, problem solving and self-organization; leadership; and social networks. These factors closely resemble many of the components of ACM, particularly the subthemes within the enabling conditions component. Given our definition of factors above, this is not surprising, but rather confirms that studies of ACM do attempt to link key components of ACM to actual outcomes.

The identified factors contributing to the success or failure of $\mathrm{ACM}$ in the actual category were then examined to determine if a similar pattern was consistently evident. We set a minimum requirement for comparability at five items and, using selective coding, considered the definition, measurement, and findings associated with each factor (i.e., social networks, learning, participation, conflict of interests) across all items in which it was found. This revealed substantial variability in precision in terms of how each factor was conceptualized and measured. For example, "participation" and "conflict of interests" tend to be colloquially employed and intuitively gauged. The interests of stakeholder groups are often poorly defined and participation suffers from a lack of rigor in assessment. Terms of engagement and power relations in reference to participation are often not dealt with in detail, and thus, the level of participation of individual groups is difficult to assess and relate to outcomes. Similarly, terminology associated with "learning" is diverse (e.g., learning, learning by doing, social learning, reproductive learning, transformative learning, loop learning, active learning, action learning, learning from experience, systematic learning, shared learning) and defined in varying detail. This diversity and the varying degree of details provided make assessment of its contribution to outcomes difficult. Only a minority of the items examined employ traceable assessment methods; primarily qualitative observations of learning characteristics that are variously understood (e.g., Fisher et al. 2007, Plummer and FitzGibbon 2007). This finding is consistent with observations about the "paradox of learning" in ACM more generally by Armitage et al. (2008). "Social networks" is another factor that receives increasing attention in ACM work as a factor contributing to success. The conceptualization of social networks is broad and ranges from simply referring to social relations as a binary variable to tightly conceptualized and highly sophisticated methods of different types of social relations stemming from the field of social network analysis. In the former case, assessment becomes difficult as social relations are ubiquitous and treatment of social networks as either present or not lends little analytical sharpness to evaluate impacts on outcomes. Studies employing more formal methods of definition and analysis make use of more clearly defined operational measures (e.g., density, cohesion, centralization) (see Bodin and Norberg 2005, Bodin and Crona
2009). The diverse conceptualizations of these factors and general lack of operational measures to assess their contribution to outcomes make it impossible currently to derive robust conclusions from experience accumulated with ACM to date.

\section{DISCUSSION}

ACM has received and is receiving considerable attention because of its potential to provide a governance form for addressing circumstances of complexity and uncertainty, as well as enhance the fit with ecosystem dynamics (Folke et al. 2005, Olsson et al. 2010). This has led to rapid conceptual development and practical uptake as witnessed in the large number of studies identified for this review. The emerging ACM literature holds the potential to offer productive insights on dealing with change.

We sought to understand the whole "complex of ACM" through this systematic review. This included characterizing the state of the literature, better understanding how ACM is defined and operationalized, and examining how aspects of ACM relate to specific outcomes. However, as the findings in the previous section reveal, the rapid, sometimes unstructured, development can also lead to considerable imprecision, inconsistency, and confusion. For example, a clear purpose or definition of ACM was absent in about half of the items containing information on successes and failures. Moreover, we found very little basis for meaningful comparisons when looking across factors in relation to successes or failures and no robust findings. This led us to abandon our further aspirations to gain knowledge about how the variables or components of ACM interrelate as well as relate to goals and outcomes. Based on our systematic review and analysis, we highlight a number of critical challenges for ACM scholarship that we see emerging from the current state of the ACM literature.

- Understanding contextual differences and the applicability of ACM. Our review shows that much of the published ACM scholarship has concentrated on North America and Europe, with the notable exception being work by CIFOR in Asia. Given the differences that exist within these locations and contexts, a pertinent question is the extent to which ACM transcends and/or is transferable across contextual differences relating to wealth/poverty, political systems, and degrees of social and ecological capital. For example, Colfer (2005) highlights the contextual nature of ACM after investigating a suite of independent variables through CIFOR's extensive experiences and finds no one variable or condition to be deterministic. Furthermore, our findings revealed a concerted focus on "typical" common-pool resources that often are managed as common property, such as forestry, fisheries, and water resources. A question that thus emerges is whether ACM is also applicable to other 
property regimes and/or environmental issues. For example, it is now being argued that ACM can significantly contribute to climate change mitigation and adaptation efforts (CIFOR 2009, May and Plummer 2011). In light of the mixed outcomes revealed in the review, such suggestions need to be evaluated.

- Identifying and stringently applying a consistent goalfor $A C M$. Adaptive comanagment generally seeks to foster the capacity for adaptation and to encourage collaboration as well as bring about positive changes aligned with social-ecological resilience (sensu Folke (2006)) and sustainability. However, the specific purpose of ACM is not clearly and consistently defined in the literature, and consensus does not exist about the intent of the concept. The range of variation in goal definition is substantial, ranging from those that are relatively specific (e.g., knowledge integration, knowledge creation) to those that are very broad (e.g., sustainability, resilience). This absence of clear and consistent purpose and the breadth of intentions make a systematic evaluation difficult and currently preclude attempts at building a coherent theory around the process and outcomes of ACM.

- Evaluating outcomes and establishing generalizable patterns of how components of ACM relate to goals and outcomes. The review revealed an extensive list of actual and potential (theorized) outcomes of ACM. Many of these outcomes are in themselves conceptually fuzzy, and their assessment or measurement are vague and context specific. For example, adaptive capacity was the third most frequently cited actual outcome and the most cited potential outcome. At the same time, conceptual clarity and measurement of adaptive capacity itself remain an issue of debate (Smit and Wandell 2006, Füssel 2007). Basing the evaluation of ACM on other equally amorphous concepts is highly problematic and necessitates deconstruction of these concepts. The review revealed 12 components of ACM comparable to those found by Plummer and Armitage (2007b) where greatest importance in terms of contribution to ACM was awarded to adaptive capacity, social learning, communication, sharing authority, and shared decision making. Factors contributing both to actual successes and failures as revealed in this review resonate with the influential variables of the ACM process identified by Plummer (2009). However, our understanding of how outcomes are linked to goals and key features of ACM nonetheless remains hampered by the fact that many studies do not adequately clarify the goals of the ACM under study, nor do they analyze the contribution of various key components of the ACM process to specific outcomes and their success or failure. The necessity of linking goals to outcomes and systematic evaluation of goal achievement emerge as two of the more important tasks for future ACM work. Although our review indicates that researchers may be focusing on outcomes related to preconceptions of what ACM will achieve (e.g., development of adaptive capacity, social-ecological resilience, sustainable resource use, enhanced efficiency and effectiveness of management, enhanced livelihoods, and creative ideas for solving problems), care should be taken to devise ways to systematically capture such anticipated outcomes of ACM processes, while also remaining open to potentially unexpected ones.

- Evaluating successes or failures of ACM. Enthusiasm about the positive outcomes of ACM has been tempered by those (e.g., Nadasdy 2007, Gondo 2009) who raise concerns about the use of the concept. Evaluation of ACM experiences in a consistent manner is, therefore, essential, but few studies successfully address this (Plummer and Armitage 2007a, Cundhill and Fabricius 2010). Colfer's (2005) work in forestry is a noteworthy exception. This systematic review reveals considerable variability in what does and/or could constitute successes or failures of ACM. In our analysis, factors such as stakeholder participation, conflict resolution, and learning came out as examples of successful outcomes of ACM as well as factors contributing to success. We need to make sure that evaluative criteria develop to more stringently assess or capture outcomes upon which appraisals of success can be made. At the same time, it is important to remember that ACM is ultimately a process (Folke et al. 2002, Carlsson and Berkes 2005), and that aspect also requires evaluation. The resiliencebased evaluative framework for ACM by Plummer and Armitage (2007a) offers assistance in this regard. They argue that resilience and resilience thinking (sensu Folke (2006), Walker and Salt (2006)) is a potentially unifying concept when evaluating ACM in the context of complex systems, as it: recognizes the three interrelated components of an ecological system, livelihoods, and process; has a normative dimension; and is situated in the milieu of changing and contested human interests. Being explicit with the normative dimension of socialecological resilience (sensu Folke (2006)) and sustainable trajectories is essential to clarifying the intent. Consistently assessing the conditions and attributes of ACM from evidentiary cases will further understanding of the initial "ten conditions for successful adaptive comanagment" and the extent to which variation is possible in different systems of interest, as put forward by Armitage et al. (2009).

In drawing upon insights gained from this systematic review, we offer some examples of best practices of ACM study design and elements to derive comparative insights in Table 9. Although we promote more precision and rigor to allow for 
Table 9. Example best practices of acm study design elements to derive comparative insights

\begin{tabular}{ll}
\hline \hline Best Practice & Illustrative Examples \\
\hline $\begin{array}{l}\text { Well-defined resource system (bounded) within which relationships among } \\
\text { phenomena can be tested }\end{array}$ & Charles 2007, Olsson et al. 2007, Evely et al. 2008 \\
$\begin{array}{l}\text { Clear definition of core concept(s) being examined } \\
\text { Specificity of goal(s) or clear intention of focus (e.g., process, attribute) with } \\
\text { regard to desired outcomes in system of concern }\end{array}$ & $\begin{array}{l}\text { Fisher et al. 2007, Kofinas et al. 2007, Schultz 2009 } \\
\text { Gxplicit criteria to assess goal(s) and/or intention of focus }\end{array}$ \\
$\begin{array}{ll}\text { Clear evidence of outcomes attributed to specific processes or attributes } \\
\text { Plumer and FitzGibbon 2007, Guidetti and Claudet 2010, Muñoz-Erickson } \\
\text { Rigorous and transparent methods that enable replication }\end{array}$ & $\begin{array}{l}\text { Bodin and Norberg 2005, Fisher et al. 2007, Cundill and Fabricius 2010, } \\
\text { Guidetti et al. 2010 } \\
\text { Bodin and Crona 2008, Fisher et al. 2007, Cundill and Fabricius 2010, } \\
\text { Guidetti and Claudet 2010 }\end{array}$ \\
\hline
\end{tabular}

systematic comparison, we also agree with Colfer (2005) who, based on her extensive experience with CIFOR's ACM project, also highlights the need to consider non-reductionist approaches. In this regard, employing methods such as qualitative meta-ethnography (Nobit and Hare 1988, Atkins et al. 2008) or qualitative and quantitative meta-synthesis (Smart 2004) may offer an alternative means to gain powerful insights into the "whole complex of ACM."

\section{CONCLUSIONS}

In his synthesis, Plummer (2009) presents a number of pertinent questions regarding ACM scholarship, such as: To what extent can variables (e.g., social and political context, properties of networks, assets employed by agencies, organizations, and individuals, attributes of organizations and individuals, key functions of individuals) be traded off? Which variables always need to be present? And which variables can improve its quality? Our findings make it clear that addressing these questions remains a formidable challenge because existing research is insufficient in terms of definitional clarity, measurement, and findings. They also reveal two interesting gaps in ACM scholarship. The first regards the matter of outcomes. Although numerous and diverse outcomes were evident, a disjuncture remains between those associated with ACM and those from ACM, as signaled by the "potential" and "actual" demarcation in the results. The second concerns the notion of success/failure. In addition to the "potential" and "actual" distinction, there was even less scholarship addressing this matter.

The issues raised in the discussion signal that ACM scholarship is at an important crossroads. This provides a valuable opportunity to think carefully about future research directions. What is the ultimate aim of ACM research? Scholars could continue along the present path of amassing research on ACM in rather unspecific and uncoordinated ways. This is somewhat natural for a young field, and progress has been and will continue to be made by this growing body of research. However, comparative studies, designed and conducted within a common framework of theory and method, are among the most powerful tools of social research, allowing stronger causal inferences and protecting against mistaken generalization (see Table 9). The current state of the ACM literature, as illustrated by this systematic review, makes it clear that achieving such causal inference and beginning to build a general theory around ACM remain a distant goal unless these issues can be addressed.

Moving forward to address this challenge may occur in several ways. Gutiérrez et al. (2011) recently employed a systematic review and meta-analysis to complete the first comprehensive assessment of attributes (social, economic, and ecological) contributing to the success of fisheries comanagment globally. In their work, 19 variables relating to comanagment attributes from Ostrom's (2009) framework were assessed to predict eight binary measures of success, from which leadership, social capital, and incentives emerged as attributes promoting successful fisheries. Even with the use of binary measures, they highlight the challenge in discerning causal connections from differentially conceived and conducted studies and echo the need for long-term data collection across contexts for meaningful empirical comparisons.

Albeit representing only one group of ACM scholars, we argue that a key aim of ACM research should be to develop theory that will help guide human-environment interactions toward sustainable trajectories. Considering how this path could be pursued while still being sensitive to context is informed by the work of Ostrom, who writes that "moving beyond panaceas to develop cumulative capacities to diagnose the problems and potentialities of linked SESs requires serious study of complex, multivariable, nonlinear, cross-scale, and changing systems" (2007:15181). In moving toward the development of a diagnostic method, she advances a nested, multi-tier framework with the intention of enabling researchers to accumulate coherent and empirical answers to questions concerning the patterns of interactions and outcomes, the relationship between endogenous governance and actions in 
the absence of external incentives or rules, and ultimately, the robustness or sustainability of the particular configuration. Constructing an analogous nested conceptual map and approach for ACM is worthy of contemplation. Organizing the many considerations (i.e., definitions, variables/ components, factors, and outcomes) revealed in this systematic review would similarly enable researchers to analyze interactions and outcomes of an empirical case. Such a framework could facilitate comparisons among cases, enhance understanding of the effects of contextual attributes, and contribute clarity to ACM scholarship. It could also fill the lacuna concerning potential and actual outcomes as well as successes/failures of ACM. As Ostrom (2009:419) stresses, "without a common framework to organize findings, isolated knowledge does not cumulate." But pursuing such aspirations requires greater precision and rigor in ACM research. It requires forethought about and adherence to specificity and consistency of concepts, definitions, measurements, and methodologies. Moving forward to improve our understanding of how ACM can contribute to sustainable humanenvironment interactions in coordinated and complementary ways will facilitate both quantitative and qualitative comparisons and circumvent limitations of drawing post hoc comparisons. It would also represent a significant step toward establishing the foundation of a theory around the concept of ACM.

Responses to this article can be read online at: http://www.ecologyandsociety.org/vol17/iss3/art11/ responses/

\section{Acknowledgments:}

The authors extend thanks to Rob de Loë and Becky Swainson for their insightful conversations about evidence-based approaches as well as to the individuals who assisted with this research project (Samantha Purdy, Joslyn Spurgeon, Steven Simpson, and Katie Vaughan). Financial support for this work is gratefully acknowledged from the Brock University Chancellor's Chair in Research Excellence, the Canadian Water Network, and the Social Sciences and Humanities Research Council of Canada. Contributions by Crona were facilitated by funding from the Swedish Research Council Formas. Crona and Olsson were also funded by Mistra through a core grant to the Stockholm Resilience Centre.

\section{LITERATURE CITED}

Armitage, D. 2007. Building resilient livelihoods through adaptive co-managment: the role of adaptive capacity. Pages 62-82 in D. Armitage, F. Berkes, and N. Doubleday, editors. Adaptive co-management: collaboration, learning and multilevel governance. UBC Press, Vancouver, British Columbia, Canada.
Armitage, D., M. Marschke, and R. Plummer. 2008. Adaptive co-management and the paradox of learning. Global Environmental Change 18:86-98. http://dx.doi.org/10.1016/j. gloenvcha.2007.07.002

Armitage, D. R., R. Plummer, F. Berkes, R. I. Arthur, I. J. Davidson-Hunt, A. Diduck, N. C. Doubleday, D. S. Johnson, M. Marschke, P. McConney, E. W. Pinkerton, and E. K. Wollenberg. 2009. Adaptive co-management for socialecological complexity. Frontiers in Ecology and the Environment 6:95-102. http://dx.doi.org/10.1890/070089

Atkins, S., S. Lewin, H. Smith, M. Engel, A. Fretheim, and J. Volmink. 2008. Conducting a meta-ethnography of qualitative literature: Lessons learnt. BMC Medical Research Methodology 8:21-31. http://dx.doi.org/10.1186/1471-2288-8-21

Ayles, B. G., R. Bell, and A. Hoyt. 2007. Adaptive fisheries co-management in the western Canadian Arctic. Pages 125150 in D. Armitage, F. Berkes, and N. Doubleday, editors. Adaptive co-management: collaboration, learning, and multilevel governance. UBC Press, Vancouver, British Columbia, Canada.

Berkes, F. 2009. Evolution of co-management: role of knowledge generation, bridging organizations and social learning. Journal of Environmental Management 90:16921702. http://dx.doi.org/10.1016/j.jenvman.2008.12.001

Berkes, F., D. Armitage, and N. Doubleday. 2007. Synthesis: adapting, innovating, evolving. Pages 308-327 in D. Armitage, F. Berkes, and N. Doubleday, editors. Adaptive comanagement: collaboration, learning, and multi-level governance. UBC Press, Vancouver, British Columbia, Canada.

Bodin, Ö., and B. I. Crona. 2008. Management of natural resources at the community level: exploring the role of social capital and leadership in a rural fishing community. World Development 36(12):2763-2779. http://dx.doi.org/10.1016/j. worlddev.2007.12.002

Bodin, Ö., and B. I. Crona. 2009. The role of social networks in natural resource governance: what relational patterns make a difference? Global Environmental Change 19(3):366-374.

Bodin, Ö., and J. Norberg. 2005. Information network topologies for enhanced local adaptive management. Environmental Management 35(2):175-193. http://dx.doi.org /10.1007/s00267-004-0036-7

Carlsson, L., and F. Berkes. 2005. Co-management: concepts and methodological implications. Journal of Environmental Management 75:65-76. http://dx.doi.org/10.1016/j.jenvman.2 $\underline{004.11 .008}$

Center for International Forestry Research (CIFOR). 2009. ACM and beyond: climate change adaptation. [online] URL: http://www.cifor.cgiar.org/acm/beyond/climate-adaptation.htm 
Charles, A. 2007. Adaptive co-management for resilient resource systems: some ingredients and the implications of their absence. Pages 83-105 in D. Armiatge, F. Berkes, and N. Doubleday, editors. Adaptive co-management: collaboration, learning and multi-level governance. UBC Press, Vancouver, British Columbia, Canada.

Charmaz, K. 2000. Grounded theory: objectivist and constructivist methods. Pages 509-536 in N. K. Denzin, and Y. S. Lincoln, editors. Handbook of qualitative research. Second edition. Sage Publications, London, UK.

Colfer, C. J. P., editor. 2005. The complex forest: communities, uncertainty, and adaptive collaborative management. RFF Press/Resources for the Future, Washington, D.C., USA.

Collaboration for Environmental Evidence. 2010. Guidelines for systematic review in conservation and environmental management. [online] URL: http://www.environmentalevidence. org/Authors.htm

Corbin, J., and A. Strauss. 2008. Basics of qualitative research. Third edition. Sage Publications, Los Angeles, California, USA.

Crowther, M. A., and D. J. Cook. 2007. Trials and tribulations of systematic reviews and meta-analyses. Pages 493-497. American Society of Hematology Education Program Book. [online] URL: http://asheducationbook.hematologylibrary.org/ cgi/content/full/2007/1/493. http://dx.doi.org/10.1182/ashedu cation-2007.1.493

Cundill, G., and C. Fabricius. 2010. Monitoring the governance dimension of natural resource co-management. Ecology and Society 15(1): 15. [online] URL: http://www.eco logyandsociety.org/vol15/iss1/art15/

Dixon-Woods, M., S. Bonas, A. Booth, D. R. Jones, T. Miller, A. J. Sutton, R. L. Shaw, J. A. Smith, and B. Young. 2006. How can systematic reviews incorporate qualitative research? A critical perspective. Qualitative Research 6(1):27-44. http: //dx.doi.org/10.1177/1468794106058867

Eavely, A. C., I. Fazey, M. Pinard, and X Lambin. 2008. The influence of philosophical perspectives in integrative research: a conservation case study in the Cairngorms National Park. Ecology and Society 13(2): 52. [online] URL: http://ww w.ecologyandsociety.org/vol13/iss2/art52/

Fabricius, C., C. Folke, G. Cundill, and L. Schultz. 2007. Powerless spectators, coping actors, and adaptive comanagers: a synthesis of the role of communities in ecosystem management. Ecology and Society 12(1): 29. [online] URL: http://www.ecologyandsociety.org/vol12/iss1/art29/.

Fabricius, C., and G. Cundill. 2010. Building adaptive capacity in systems beyond the threshold. Pages 43-68 in D. Armitage and R. Plummer, editors. Adaptive capacity and environmental governance. Springer-Verlag, Berlin, Germany. http://dx.doi.org/10.1007/978-3-642-12194-4 3

Fisher, R., R. Prabhu, and C. MacDougall, editors. 2007. Adaptive collaborative management of community forests in Asia. Center for International Forestry Reserach, Bogor, Indonesia.

Fennell, D., R. Plummer, and M. Marschke. 2008. Is adaptive co-management ethical? Journal of Environmental Management 88(1):62-75.

Folke, C. 2006. Resilience: the emergence of a perspective for social-ecological systems analysis. Global Environmental Change 16:253-267. http://dx.doi.org/10.1016/j.gloenvcha.2 $\underline{006.04 .002}$

Folke, C., S. Carpenter, T. Elmqvist, L. Gunderson, C. S. Holling, B. Walker, J. Bengtsson, F. Berkes, J. Colding, K. Danell, M. Falkenmark, M. Moberg, L. Gordon, R. Kaspersson, N. Kautsky, A. Kinzig, S. A. Levin, K.G. Mäler, L. Ohlsson, P. Olsson, E. Ostrom, W. Reid, J. Rockstöm, S. Savenije, and U. Svedin. 2002. Resilience and sustainable development: building adaptive capacity in a world of transformations. Report for the Swedish Environmental Advisory Council Ministry of the Environment, Stockholm, Sweden.

Folke, C., T. Hahn, P. Olsson, and J. Norberg. 2005. Adaptive governance of social-ecological systems. The Annual Review of Environment and Resources 30:441-473. http://dx.doi.org/ 10.1146/annurev.energy.30.050504.144511

Füssel, H-M. 2007. Vulnerability: a generally applicable conceptual framework for climate change research. Global Environmental Change 17:155-167. http://dx.doi.org/10.1016/ j.gloenvcha.2006.05.002

Galaz, V., T. Hahn, P. Olsson, C. Folke, and U. Svedin. 2008. The problem of fit among biophysical systems, environmental and resource regimes, and broader governance systems: insights and emerging challenges. Pages 147-186 in O. Young, L. A. King, and H. Schroeder, editors. Institutions and environmental change: principal findings, applications, and research findings. MIT Press, Cambridge, Massachusetts, USA.

Garaway, C. J., and R. I. Arthur. 2004. Adaptive learning: a practical framework for the implementation of adaptive comanagement-lessons from selected experiences in South and Southeast Asia. MRAG Ltd., London, UK.

Glaser, B. G., and A. L. Strauss. 1967. The discovery of grounded theory: strategies for qualitative research. Aldine Publishing Company, Chicago, Illinois, USA.

Gondo, T. 2009. Adaptive co-management of natural resources: a solution or part of the problem? 2009 Amsterdam Conference on the Human Dimensions of Global 
Environmental Change, 2-4 December 2009, Amsterdam, The Netherlands. [online] URL: http://www.earthsystemgove rnance.org/ac2009/index.php?page=papers.

Guidetti, P., S. Bussotti, F. Pizzolante, and A. Ciccolella. 2010. Assessing the potential of an artisanal fishing co-management in the marine protected area of Torre Guaceto (southern Adriatic Sea, SE Italy). Fisheries Research 101:180-187. htt p://dx.doi.org/10.1016/j.fishres.2009.10.006

Guidetti, P., and J. Claudet. 2010. Comanagement practices enhance fisheries in marine protected areas. Conservation Biology 24(1):312-318. http://dx.doi.org/10.1111/j.1523-173 9.2009.01358.x

Gunderson, L. H., C. S. Holling, and S. Light. 1995. Barriers and bridges to renewal of ecosystems and institutions. Columbia University Press, New York, New York, USA.

Gutiérrez, N. L., R, Hilborn, and O. Defeo. 2011. Leadership, social capital and incentives promote successful fisheries. Nature 470(7334):386-389. http://dx.doi.org/10.1038/nature0 $\underline{9689}$

Hughes, N., S. J. Closs, and D. Clark. 2009. Experiencing cancer in old-age: a qualitative systematic review. Qualitative Health Research 19(8):1139-1153. http://dx.doi.org/10.1177 $\underline{1049732309341715}$

Huitema, D., E. Mostert, W. Egas, S. Moellenkamp, C. PahlWostl, and R. Yalcin. 2009. Adaptive water governance: assessing the institutional prescriptions of adaptive (co) management from a governance perspective and defining a research agenda. Ecology and Society 14(1):26. [online] URL: http://www.ecologyandsociety.org/vol14/iss1/art26

Kofinas, G. P., S. J. Herman, and C. Meek. 2007. Novel problems require novel solutions: innovation as an outcome of adaptive co-management. Pages 249-267 in D. Armitage, F. Berkes, and N. Doubleday, editors. Adaptive comanagement: collaboration, learning and multi-level governance. UBC Press, Vancouver, British Columbia, Canada.

Lee, K. 1993. Compass and gyroscope: integrating science and politics for the environment. Island Press, Washington, D. C., USA.

May, B., and R. Plummer. 2011. Accommodating the challenges of climate change adaptation and governance in conventional risk management: adaptive collaborative risk management (ACRM). Ecology and Society 16(1):47. [online] URL: http://www.ecologyandsociety.org/vol16/iss1/art47/

Miles, M. B., and A. M. Huberman. 1994. Qualitative data analysis. Second edition. Sage Publications, Thousand Oaks, California, USA. http://dx.doi.org/10.2307/2392365

Muñoz-Erickson, T. A., B. Aguilar-González, M. R. Loeser, and T. D. Sisk. 2010. A framework to evaluate ecological and social outcomes of collaborative management: lessons from implementation with a northern Arizona collaborative group. Environmental Management 45:132-144. http://dx.doi.org/10 $.1007 / \mathrm{s} 00267-009-9400-\mathrm{y}$

Nadasdy, P. 2007. Adaptive co-management and the gospel of resilience. Pages 208-227, in D. Armitage, F. Berkes, and N. Doubleday, editors. Adaptive co-management: collaboration, learning and multilevel governance. UBC Press, Vancouver, British Columbia, Canada.

Nobit G. W., and R. D Hare. 1988. Meta-ethnography: synthesizing qualitative studies. Sage Publications, Newbury Park, California, USA.

O'Connell, R., and S. Downe. 2009. A metasynthesis of midwives' experience of hospital practice in publicly funded settings: compliance, resistance and authenticity. Health: An Interdisciplinary Journal for the Social Study of Health, Illness and Medicine 13(6):589-609.

Olsson, P., C. Folke, and F. Berkes. 2004. Adaptive comanagement for building resilience in social-ecological systems. Environmental Management 34(1):75-90. http://dx. doi.org/10.1007/s00267-003-0101-7

Olsson, P., C. Folke, V. Galaz, T. Hahn, and L. Schultz. 2007. Enhancing the fit through adaptive co-management: creating and maintaining bridging functions for matching scales in the Kristianstads Vattenrike Biosphere Reserve Sweden. Ecology and Society 12(1):28. [online] URL: http://www.ecologyands ociety.org/vol12/iss1/art28/

Olsson, P., Ö Bodin, and C. Folke. 2010. Building transformative capacity for ecosystem stewardship in socialecological systems. Pages 263-286 in D. Armitage, and R. Plummer, editors. Adaptive capacity and environmental governance. Springer-Verlag, Berlin, Germany. http://dx.doi. org/10.1007/978-3-642-12194-4 13

Ostrom, E. 2007. A diagnostic approach for going beyond panaceas. Proceedings of the National Academy of Science 104:15181-15187. http://dx.doi.org/10.1073/pnas.0702288104

Ostrom, E. 2009. A General Framework for analyzing sustainability of social-ecological systems. Science 24(5939): 419-422. DOI: 10.1126/science.1172133 http://dx.doi.org/10 $\underline{.1126 / \text { science. } 1172133}$

Ostrom, E., T. Dietz, N. Dolsak,, P. C. Stern, S. Stonich, and E. U. Weber, editors. 2002. The drama of the commons. National Academy Press, Washington, D.C., USA.

Petticrew, M., and H. Roberts. 2006. Systematic reviews in the social sciences: a practical guide. Blackwell Publishers, Malden, Massachusetts, USA.

Plummer, R. 2009. The adaptive co-management process: an initial synthesis of representative models and influential variables. Ecology and Society 14(2):24. [online] URL: http:/ /www.ecologyandsociety.org/vol14/iss2/art24/ 
Plummer, R., and D. Armitage. 2007a. A resilience-based framework for evaluating adaptive co-management: linking ecology, economy and society in a complex world. Ecological Economics 61:62-74.

Plummer, R., and D. R. Armitage. 2007b. Charting the new territory of adaptive co-management: a Delphi study. Ecology and Society 12(2): 10. [online] URL: http://www.ecologyand society.org/vol12/iss2/art10/

Plummer, R., and J. E. FitzGibbon. 2007. Connecting adaptive co-management, social learning and social capital through theory and practice. Pages 38-61 in D. Armiatge, F. Berkes, and N. Doubleday, editors. Adaptive co-management: collaboration, learning and multi-level governance. UBC Press, Vancouver, British Columbia, Canada.

Plummer, R., and A. Hashimoto. 2011. Adaptive comanagement and the need for situated thinking in collaborative conservation. Human Dimensions of Wildlife Management 16:222-235. http://dx.doi.org/10.1080/10871209.2011.585434

Pullin, A. S., and T. M. Knight. 2009. Doing more good than harm-building an evidence-base for conservation and environmental management. Biological Conservation 142:931-934. http://dx.doi.org/10.1016/j.biocon.2009.01.010

Pullin, A. S., and G. B. Stewart. 2006. Guidelines for systematic review in conservation and environmental management. Biological Conservation 20(6):1647-1656. htt p://dx.doi.org/10.1111/j.1523-1739.2006.00485.x

Rahimi, B., V. Vimarlund, and T. Timpka. 2009. Health information system implementation: a qualitative metaanalysis. Journal of Medical Systems 33:359-368. http://dx.d oi.org/10.1007/s10916-008-9198-9

Schultz, L. 2009. Nurturing resilience in social-ecological systems. Dissertation, Stockholm University, Stockholm, Sweden.

Smart, J. C., editor. 2004. Higher education: handbook of theory and research. Vol. XIX. Kluwer Academic Publishers, Dordrecht, The Netherlands. http://dx.doi.org/10.1007/1-402 0-3279-X

Smit, B., and J. Wandel. 2006. Adaptation, adaptive capacity and vulnerability. Global Environmental Change 16:282-292. http://dx.doi.org/10.1016/j.gloenvcha.2006.03.008

Thorne, S., L. Jensen, M. H. Kearney, G. Nobit, and M. Sandelowski. 2004. Qualitative meta-synthesis: reflections on methodological orientation and ideological agenda. Qualitative Health Research 14(10):1342-1365.

Walker, B., and D. Salt. 2006. Resilience thinking. Island Press, Washington, D.C., USA. 
APPENDIX \#1. Systematic review and analysis methodology

In this appendix, we detail how the systematic review and analysis of the ACM literature was conducted. Our approach was informed by both synthesis based methodologies in social sciences with a qualitative orientation (Petticrew and Roberts 2006, Atkins et al. 2008, Rahimi, Vimarlund and Timpka 2009) as well as the guidelines set forth in biological conservation (Pullin and Stewart 2006, Pullin and Knight 2009). We specifically undertook the following steps.

Step One: Question definition. We began by identifying several aspects of ACM that lacked clarity or consensus. These aspects are conveyed in the objectives of the review: (1) to characterize the state of the ACM literature, (2) to enhance our holistic understanding of ACM, and (3) to examine relationships among aspect of ACM based on accumulated experiences to date. More specific questions were then formulated in association with the objectives. These include: the context(s) in which it is being undertaken, the orientation with which it is being investigated, its definition (purpose(s)), the components (variables) associated with it, the outcomes from the process or policy, its successes and failures, and ultimately, the relationships among these aspects and the outcomes.

Step Two: Search protocol. The second step of the systematic review is to design how the search will be conducted. This involves a series of decisions about how the data will be acquired and its relevance gauged. In an effort to be as comprehensive as possible we searched using the key terms: ecosystem or ecolog* or environment* or natural resource and ACM or adaptive comanagement or adaptive collaborative management. To capture both peer-reviewed and non peer-reviewed (gray) literature, searches were carried out using academic databases (Google Scholar, SCOPUS, Proquest, Science Direct, JSTOR and Scholars Portal E-Journals), the personal libraries of the researchers and the internet. In the case of the latter, the search engine Google was used with the first 50 "hits" fully viewed and the next 50 were checked for relevance (Collaboration for Environmental Evidence 2010). The search for items was ceased when personal libraries of the researchers were exhausted and all identified sources for the searches were completed. An acknowledged limitation of the search is that only items in English and in print were considered.

Step Three: Screening of results. The initial search was liberal and yielded 414 citations for items. Criteria were then set to screen these initial citations, as per the suggestion of Petticrew and Roberts (2006). The title, abstract and keywords of the citations were then considered according to the criteria of date (between 1997 and present [May, 2010]), language (written in English), and relevance of topic (social-ecological systems, natural resource management, environment-human interactions). The uses of terms or labels in the search protocol were not judged by the researchers or used as a screening criterion because doing so would interfere with the objectives of the study. Consequently, 298 citations were excluded from the systematic literature review. The full text of each remaining item was retrieved and then further scrutinized for compatibility with the questions posed in this research. As an outcome of the screening process, 108 items were included in the systematic review and organized into a QSR NVIVO database. The term "items" is used to encompass the many forms of data included in this review (e.g., articles, reports, theses, books, book chapters, papers presented at conferences). As a rule, 
each item was considered as an item of data. However, an important exception was made with the treatment of one book (Colfer 2005) and one thesis (Schultz 2009). These documents comprised multiple chapters and articles, but were treated as one item because of their coherent unifying framework.

Step Four: Analysis. A grounded theory approach was employed to analyze the data. Grounded theory originated with the work of Glaser and Strauss (1967) and stresses the uncovering of theory from data as generated through comparative analysis. In following Corbin and Strauss (2008:1), we use the term grounded theory in a generic sense to denote “...theoretical constructs derived from qualitative analysis". Using this method, analysis occurs through the iterative rounds of coding. Coding is a process by which textual data (usually) is read and concepts are extracted and their properties and dimensions developed (Miles and Huberman 1994, Charmaz 2000, Corbin and Strauss 2008). Accordingly, analyzing data for concepts in this research occurred through three types of coding:

1) Open coding took place in the first pass through the data and involves identifying and capturing all possibilities and potentials. Labels named to represent the concept extracted are affixed to textual passages.

2) Axial coding identifies patterns and establishes evidence (or lack of evidence). In revisiting the textual passages, similar concepts are grouped together and groups of concepts emerge with varying degrees of frequency and magnitude. In this paper we use the term "category" to denote the main classes of concepts and the term "theme" to describe groupings of concepts with respect to their relative frequency of mention. 3) Selective coding examines relationships and integrates core concepts to refine theoretical constructions. Throughout the findings presented in the paper selective passages are used as illustrative examples. 
APPENDIX \# 2. Detailed description of coding related to each aim

1) Broad characterization of the state of the ACM literature

As ACM research is an amalgam of different types of scholarship - ranging from conceptual to the applied - axial coding was undertaken to discern the primary orientation of each item

reviewed. An item was thus considered to be theoretical if it was purely conceptual and stated so explicitly, or if it had a strong conceptual flavor drawing on empirical examples, but where these cases could not be considered primary empirical data. The item was categorized as empirical if it relied purely on analysis of one or several cases, presented primary data and stated so explicitly or if it had a conceptual flavor but also presented original evidence.

2) Understanding how ACM is defined

To examine how ACM was defined across items we looked for explicit statements of purpose, or the presence of key terms, such as purpose, aim and intention. Given the systematic review and analysis of the research, consideration was also directed at implicit statements of intent. Implicit statements were interpreted and coded under the label 'purpose' if the item conveyed the intent of the ACM action. Some items mentioned multiple purposes and these were each considered and coded separately.

3) Identifying components of the ACM process

Our query into identifying the components (variables) of ACM began with the open coding of all items. Passages were identified which explicitly labeled or implicitly recognized variables of ACM. After the variables were identified through the process of open coding, axial and selective coding were used in a second pass through all of the items to identify all relevant material associated with the themes and to probe the relationships between them.

4) Identifying which outcomes of ACM are being realized

Our query into clarifying the outcomes from the ACM process began with the open coding of all items. In this initial pass through the data the results occurring as a consequence from the ACM process (either during or afterwards) were identified. These preliminary concepts were used as a basis to affix themes to the text data during the second pass of axial coding. Selective coding was then used to further probe the relationship among the outcomes the emerged.

5) Identifying outcomes - success and failure

Open coding began by identifying passages conveying information on success or failure. Axial coding was subsequently used in the second pass through the data to label text data.

6) Drawing insights on how aspects of ACM relate to outcomes

Selective coding was used to examine relationships between categories. In drawing upon categories previously established through axial coding, the category of successes and failures was first examined in relation to the category of purpose. Open coding was then employed to identify factors contributing to the success or failure of ACM. We define factors as key variables or components as well as contextual elements that influence the success or failure of ACM. Axial coding was used to categorize these factors and then selective coding was used to examine their relationship with the categories of actual success and actual failures. We concentrated on the 
'actual' category (as opposed to the more speculative potential category) and set a minimum number required for comparability at five items. This number was an arbitrary threshold, but given the low numbers of items for comparisons we believed it would provide some level of 'robustness' for generalizability of assertions if consistency was evident across the items. For each factor (social networks, social learning, participation, conflict of interests) meeting these criteria, we employed open coding to examine them, then went back to the original data in terms of the definition, measurement and findings associated. For example, how did all the items containing the factor social networks define the term, how did they each measure social networks, and what were the findings of the study? Selective coding was then employed to examine these relationships across all items in which the factor was found to determine if anything could be said with comparative consistency. 